\title{
P02.26. Integrative care for adolescent mood problems: brief report from a second opinion clinic
}

\author{
K Kemper $^{1 *}$, B Banasiewicz ${ }^{2}$ \\ From International Research Congress on Integrative Medicine and Health 2012 \\ Portland, Oregon, USA. 15-18 May 2012
}

\section{Purpose}

To improve the quality of service and inform care for patients interested in integrative care, we conducted a chart review to describe a) patients whose families had concerns about mood; b) families' interest in health promotion topics; and c) clinical recommendations.

\section{Methods}

Patients were included if their intake form indicated a concern about mood or depression. We reviewed the comprehensive intake form, physician notes, and laboratory test results. This study was approved by the Wake Forest School of Medicine Institutional Review Board.

\section{Results}

Of the 75 new patients, 34 (45\%) noted a concern about mood. The average age was $13 \pm 4$ years, $68 \%$ were female, and patients had an average of 8.6 health concerns such as fatigue, anxiety, headaches, constipation, and pain. Most (88\%) received care from other specialists and $71 \%$ took medications (average 2.4/patient), most often antidepressants. There was great interest in discussing stress management (86\%), nutrition (84\%), sleep (82\%), and exercise/activity (78\%). Most had suboptimal levels of ferritin (65\%) and vitamin D (65\%). Most parental questions were about fish oil (82\%), multivitamins (48\%), and minerals (63\%).

\section{Conclusion}

Physicians offering integrative care for adolescents with mental health concerns should be prepared to offer advice about healthy lifestyle, particularly stress

${ }^{1}$ Wake Forest University Health Sciences, Winston-Salem, USA

Full list of author information is available at the end of the article management, nutrition and nutritional supplements, sleep, and exercise.

\section{Author details}

${ }^{1}$ Wake Forest University Health Sciences, Winston-Salem, USA. ${ }^{2}$ University of South Carolina, Columbia, USA.

Published: 12 June 2012

doi:10.1186/1472-6882-12-S1-P82

Cite this article as: Kemper and Banasiewicz: P02.26. Integrative care for adolescent mood problems: brief report from a second opinion clinic. BMC Complementary and Alternative Medicine 2012 12(Suppl 1):P82.
Submit your next manuscript to BioMed Central and take full advantage of:

- Convenient online submission

- Thorough peer review

- No space constraints or color figure charges

- Immediate publication on acceptance

- Inclusion in PubMed, CAS, Scopus and Google Scholar

- Research which is freely available for redistribution
() Biomed Central

\section{() Biomed Central}

